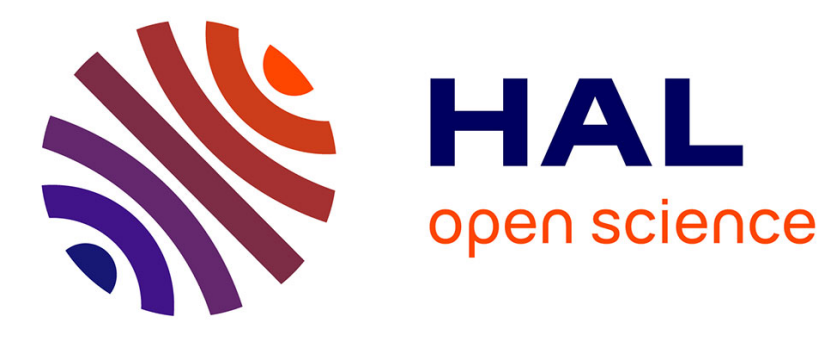

\title{
Designing Therapeutic Projects Within Multiprofessional Health Teams: Integrating the Dimension of Work
}

Carmo Alonso, Pascal Beguin, Valérie Pueyo, Francisco Duarte

\section{To cite this version:}

Carmo Alonso, Pascal Beguin, Valérie Pueyo, Francisco Duarte. Designing Therapeutic Projects Within Multiprofessional Health Teams: Integrating the Dimension of Work. Proceedings of the 20th Congress of the International Ergonomics Association (IEA 2018), In press. hal-01981532

\section{HAL Id: hal-01981532 \\ https://hal.science/hal-01981532}

Submitted on 15 Jan 2019

HAL is a multi-disciplinary open access archive for the deposit and dissemination of scientific research documents, whether they are published or not. The documents may come from teaching and research institutions in France or abroad, or from public or private research centers.
L'archive ouverte pluridisciplinaire HAL, est destinée au dépôt et à la diffusion de documents scientifiques de niveau recherche, publiés ou non, émanant des établissements d'enseignement et de recherche français ou étrangers, des laboratoires publics ou privés. 


\title{
Designing Therapeutic Projects Within Multiprofessional Health Teams: Integrating the Dimension of Work
}

\author{
Carolina Maria do Carmo Alonso ${ }^{1(\&)}$, Pascal Béguin ${ }^{2}$, Valerie Pueyo $^{2}$, and Francisco Duarte ${ }^{3}$ \\ ${ }^{1}$ Department of Occupational Therapy, Medicine School, University of Rio de Janeiro, Rio de Janeiro, Brazil \\ Carolina.alonso@ufrj.br, Institute for Work Studies of Lyon, University Lumière, Lyon 2, Lyon, France ${ }^{3}$ Production \\ Engineering Program, COPPE, Federal University of Rio de Janeiro, Rio de Janeiro, Brazil
}

\begin{abstract}
This paper aims to demonstrate how the design of Therapeutic Plan (TP) is carried out by professionals of multi professional teams of Primary Care in Brazil. It is a qualitative research guided by the theoretical framework of Activity Ergonomics which included professionals from a Family Health Team (FHT) composed of: one physician, one nurse, one nursing assistant and six community health agents. The procedures of data collection were interviews and sistematic observations. The results demonstrate that the spaces for collective production of the activity, recommended for the construction of the TP, are insufficient to integrate the information coming from the real situation, as well as, to coordinate the actions that aim to solve the problems that emerge in the daily life of the service. In addition, the process of designing the TPs is still very handcrafted and little instrumentalized to favor the exchange between the different actors of the team. This frame indicates the need to deepen studies that can support the strengthening of tools and processes that favor the collective fabrication of work in the context of the Teamwork in Primary Care.
\end{abstract}

Keywords: Ergonomics, Teamwork, Health workforce

\section{Introduction}

The evolution of the complexity of health care motivated the transformation of work in this field from a solo performance centered on the role of the physician to an orchestrated performance with different professionals working together to design and implement a treatment plan [1-4]. According to Weel [1], multiprofessional health teamwork has allowed the improvement of the management of complex cases, espe- cially in home and community care, in long term care for chronic disease, in oncology and in palliative care.

In this context, the team meeting is one of the pillars for the effectiveness of the multidisciplinary work, characterizing itself as a discussion session in which each professional offers his perspective on a case. Those meetings facilitate the development

of essential components for the collective care, such as: interprofessional learning, information exchange, decision making, coordination, planning and monitoring of the work process [4-6].

In Brazil, the multidisciplinary team work, as well as the team meetings, are foreseen in the regulations of different services that make up the public health care network $[7,8]$. However, there are few studies that specifically investigated how team meetings occur in the Brazilian context $[9,10]$. In contrast the international literature has published a number of researches on the organization of such devices in various areas such as oncology $[11,12]$, mental health and primary care with studies that discuss cost effectiveness [13] as well as explore how professionals evaluate this practice.

Thus, this article takes as object of study the organization of the team meetings in the Primary Care service in Brazil, aiming to raise characteristics of the organization of the team meetings to discuss, in the light of the theoretical reference of the Activity Ergonomics, limits and potentialities for the development of the Therapeutic Plans (TP).

\subsection{Study Design and Setting}

This study is addressed to the field of qualitative research being guided by the theo- retical framework of the Activity Ergonomics (AE). The object of study of (AE) is the content of the work and its effects for the health of the working population and also for production. Thus, it is expected that knowledge generated 
from the EA studies will provide subsidies that support transformations of work situations in their multiple dimensions $[14,15]$.

Data collection was performed in five stages that occurred in January to September 2015. The research site was a primary health care service located in the northern part of the city of Rio de janeiro, which had four multiprofessional teams.

\subsection{Sample and Study Procedures}

Data collection focused on observations of team meetings. The weekly meetings of the four multiprofessional service teams were monitored during the four-month period. Audio records of the discussions were done, as were notations in research diries.

We sought with these procedures to obtain data on: the ways in which the meetings were organized, the number and nature of the cases discussed and the different pos- sibilities of interaction that occurred among the professionals of the ESF teams. The follow-up of the team meetings was suspended according to the saturation criterion that defines a sample when the data obtained present redundancy or repetition [16].

\subsection{Data Analysis}

The data collected were analyzed using the precepts of Franco (2008) for content analysis in three stages: (I) Pre-exploration of the material. (II) Selection of the units of analysis. (III) Reordering of the material and categorization. Thus a preliminary report was elaborated that dealt with the functioning of the team meetings which was vali- dated with the workers in a group composed of representatives of the four teams. This procedure had the purpose of validating: the analyzes, the results and the conclusions of the intervention.

Therefore, through the validation or refutation of these workers, the report was then redone. It should be noted that the discussions at this meeting were recorded and transcribed to facilitate the analysis of its content and the reconstruction of the final research report that originated this article.

\subsection{Observations on Research Ethics}

Regarding the ethics procedures in research, the research project was submitted to the Research Ethics Committee of the University Hospital Clementino Fraga Filho of UFRJ obtaining approval under the number 42680415.5.0000.5257. All data collection procedures were marked by the voluntary participation of the subjects by reading and signing the Term of Free and Informed Consent. In addition, to avoid embarrassing names and other information that could somehow identify users or workers of family health teams, they were omitted.

\section{Results}

The results of this research indicated that the guidelines for carrying out the staff meeting on primary health care in Brazil can be summarized in the mandatory presence of all team members in a meeting aimed at planning and evaluation of the actions that are built to solve the problems health of the population ascribed $[17,18]$.

Nevertheless, such recommendations are generic and provide little data to support the operationalization of service meetings. Therefore, the data collected by this research focused on revealing key dimensions related to the functioning of team meetings, such as: periodicity and duration of meetings; records of the discussions and landmarks of the cases; places to meet and models of organization of the meetings.

\subsection{Periodicity and Duration of Meetings}

As regards the periodicity of team meetings, it was verified that the four teams hold a weekly meeting, in pre-defined hours. This organization aims to avoid simultaneous meetings that would withdraw many 
professionals from work with the population served by the service. Thus, while one team meets, the other three are responsible for the care of the users under the responsibility of the absent team. Regarding the duration of the meetings, the average time of the meetings accompanied by this research was three hours, and this meeting period is guaranteed in the weekly schedule of the professionals of the teams.

\subsection{Record of Case Management Discussions in Team Meetings}

The record of all meetings followed was done by the nurses, in the team's minutes notebooks, and consisted of notes on agreements made on the handling of cases. However, to retrieve the issues under discussion, team professionals used predomi- nantly individual notes or data that were searched in the medical records.

Such a framework denotes that the minutes notebooks are made as a way of formally registering the meetings, but they are not used as a basis for the construction and monitoring of the TP, since there is, in fact, no collective instrument used as a basis for sharing actions that were being designed and implemented by the teams.

\subsection{Places to Meet}

The meetings observed were always outside the medical offices, because these spaces do not accommodate all members of the teams. Besides, it was noted that in the service studied there was no place reserved for holding meetings, often requiring extra work from the team that needed to negotiate with other professionals of the service the use of larger rooms, such as the auditorium of the service.

The lack of space defined for the meetings had the following consequences: delays, frequent interruptions or early termination of the meeting to release space for another activity. It should also be noted that on one occasion accompanied in this study the team could not guarantee a room and the meeting was held in the garden of the health unit.

\subsection{Models of Organization of the Meetings}

The meetings followed in this research showed a great diversity of organization models. In order to analyze this issue, the two meetings that presented the most contrast were chosen in terms of the number and nature of the cases discussed and the data used in the comparison are presented in Table 1.

Table 1.

\begin{tabular}{|l|}
\hline Team A \\
\hline $2 \mathrm{~h} 40$ \\
\hline 15 \\
\hline Health issues, reports on the organization of team work \\
\hline Doctor, nurse, community health agent, physiotherapist \\
\hline
\end{tabular}

Compared items

Duration of the meeting

Number of cases discussed

Nature of the topics covered in the meeting Professionals present in the discussion

Team B 2h33

4

Health issues, evaluation and planning of health promotion group, reports on team work organization Doctor, nurse, community health agent 
Team A discussed the largest number of cases by arranging the meeting in two well- defined steps. The first stage was devoted to the passage of reports and the second to the discussion of cases, which were listed at the beginning of the meeting. At that meeting, there was little interaction between the different team members, and the discussions about the cases were brief, encompassing only aspects guided by medical semiology.

In relation to the organization team B meeting, it was observed that the cases were discussed without previous listing. With regard to the design of the discussions, these were interspersed with reports on the organization of the team's work. It should be noted that this team discussed a significantly lower number of cases, however, there was a greater interaction between the different actors of the team that included social aspects such as territorial data and the questions about family organization.

\section{Discussion}

When team meetings are well planned, they become privileged spaces for the design of user-centered therapeutic plans, producing more effective results in the management of complex cases $[18,19]$. However, few studies have explored how these meetings are organized by mapping aspects that may limit or favor the achievement of the expected results [20].

The results of this research pointed out that normative texts offer little guidance on how team meetings in primary care should be organized. This leaves open questions regarding the operationalization of the team meetings, such as the estimation of the frequency and duration of the meetings, and also what resources the workers need to have to carry out this activity.

The investigation of the actual work of the teams has revealed many weaknesses that need to be overcome in order to carry out the meetings that are reflected in an overload for the workers and impose limits for the design of the therapeutic projects. Workers' overload may be evidenced by the lack of adequate space to bring teams together. This requires additional work to the team members who always need to negotiate the place to carry out this activity. Moreover, at the time when it was not possible to negotiate the space to hold the meeting, this occurred in the garden of the unit, which underlines the idea that although the meetings are considered essential for the design of the therapeutic projects, the consideration of objective conditions for its realization is still little considered in planning the work in primary care.

Workers' investment, which often does not have a satisfactory return, is related to the construction of TP and still produces deleterious effects on the workers health. The meeting that took place in the service garden was an emblematic example of this situation, since the holding of the meeting there imposed limits on the discussion of cases, since confidential data could not be exposed in that environment where other workers and users of the service circulated freely. On the other hand, the workers were exposed to excessive heat, noises and made the notes without furniture suitable for this.

In short the results demonstrate that the spaces for collective production of the activity, recommended for the construction of the TP, are insufficient to integrate the information coming from the real situation, as well as, to coordinate the actions that to solve the problems that emerge in the daily life of the service. In addition, the process of designing the TPs is still very handcrafted and little instrumentalized to favor the

Designing Therapeutic Projects Within Multiprofessional Health Teams 1977

exchange between the different actors of the team. This frame indicates the need for deepen studies that support the strengthening of tools and processes that favor the collective fabrication of work in the context of the Teamwork in Primary Care.

\section{References}

1. van Weel C (1994) Teamwork. Lancet 344(8932):1276-1279

2. Blachman NL, Blaum CS (2016) Integrating care across disciplines. Clin Geriatr Med 
3. Grumbach K, Bodenheimer T (2004) Can health care teams improve primary care practice?

JAMA 291(10):1246-1251

4. Dorman S, Smith V, Kirkham S (2010) The use of an electronic patient record to facilitate a specialist palliative care multidisciplinary team meeting. Palliat Med 24(2):198

5. Van Houdt S, De Lepeleire J, Driessche KV, Thijs G, Buntinx F (2011) Multidisciplinary team meetings about a patient in primary care: an explorative study. J Prim Care Community

Health 2(2):72-76

6. Brunner $\mathrm{M}$ et al (2015) Head and neck multidisciplinary team meetings: effect on patient management. Head Neck 37(7):1046-1050

7. vanDongenJJJ,vanBokhovenMA,DaniëlsR,LenzenSA,vanderWeijdenT,BeurskensA (2010) Interprofessional primary care team meetings: a qualitative approach comparing observations with personal opinions. Fam Pract. https://doi.org/10.1093/fampra/cmw106

8. Raine R, Raine R, a'Bháird CN, Xanthopoulou P, Wallace I, Ardron D, Harris M, Barber J, Prentice A, Gibbs S, King M, Blazeby JM (2015) Use of a formal consensus development technique to produce recommendations for improving the effectiveness of adult mental

health multidisciplinary team meetings. BMC Psychiatry 15(1):143

9. BRASIL PORTARIA No 4.279, DE 30 DE DEZEMBRO DE 2010. Estabelece diretrizes para a organização da Rede de Atenção à Saúde no âmbito do Sistema Único de Saúde (SUS)

10. Santos EOD, Coimbra VCC, Kantorski LP, Pinho LBD, Andrade APMD, Eslabão AD (2017) Reunião de equipe: proposta de organização do processo de trabalho. Revista de Pesquisa: Cuidado é Fundamental Online 9(3):606-613. Rio de Janeiro

11. Santa Cruz ML et al (2014) Reunião de equipe: uma reflexão sobre sua importância enquanto estratégia diferencial na gestão coletiva no Programa de Saúde da Família (PSF).

Psicologia Revista 17(1/2):161-183

12. Fletcher TE, Ali H, Ryall C, Beeching NJ, Joekes E, Lewthwaite P (2012) The benefits of an infectious disease/radiology multidisciplinary team meeting. J Infect 65(4):363-365

13. Zarzavadjian Le Bian A, Costi R, Bruderer A, Herve C, Smadja C (2014) Multidisciplinary team meeting in digestive oncology: when opinions differ. Clin Transl Sci 7(4):319-323

14. Chinai N, Bintcliffe F, Armstrong EM, Teape J, Jones BM, Hosie KB (2013) Does every patient need to be discussed at a multidisciplinary team meeting? Clin Radiol 68(8):780-784

15. Guérin F, Laville A, Daniellou F, Duraffourg J, Kerguelen A (2001) Compreender o trabalho para transformálo: a prática da ergonomia. In: Compreender o trabalho para transformá-lo: a 
prática da ergonomia

16. Abrahão J (2009) Introdução à ergonomia: da prática à teoria

17. Fontanella BJB, Ricas J, Turato ER (2008) Amostragem por saturação em pesquisas

qualitativas em saúde: contribuições teóricas. Cadernos de saúde pública 24:17-27

18. Brazil (2012)

19. Rio de janeiro (2011) 